\title{
BEYOND THE WALLS: LOCATING THE COMMON DENOMINATOR IN HEROD'S LANDSCAPE PALACES
}

\author{
EVIE GASSNER
}

The Hebrew University of Jerusalem,e-mail: evi.karafelov@mail.huji.ac.il

Received: $28^{\text {th }}$ June 2017, Accepted: $18^{\text {th }}$ December 2017

\begin{abstract}
The Question of King Herod's personal involvement in the Building Projects attributed to him was always one of the more dominant topics in the study of Herodian archaeology. The purpose of this short paper is to try and answer this question by researching and discussing the location of a 'common denominator' in the structure of Herod's "Landscape" palaces, through the study of the relationship each palace has with its surroundings. These palacesthe Promontory Palace in Caesarea, the Third Palace in Jericho, the Northern Palace in Masada and the Palace of Great Herodium- were chosen as case studies for their scale, architectural complexity and the unique connection they share with the landscape. While a close study of the interior of the palaces and their structural units show that each palace plan is unique and shares almost nothing in common with the other plans, a research of the landscape in which the palaces are located indicates that a common denominator to all four palaces can be found in the forms of the elements of water and the dramatic landscape. These two elements, combined with the uniqueness of the structures themselves, point to Herod's own involvement in the planning of the four "Landscape" palaces .
\end{abstract}

Keywords: Herod, Landscape, Palaces, Water

\section{INTRODUCTION}

\section{Herod and his Projects.}

One of the more dominant topics in the study of Herodian architecture is the question of King Herod's personal involvement in his building projects - that is to say, the scope of it and whether he was directly responsible for the projects themselves. There are several opinions on this issue ${ }^{1}$ - the two most dominant of which are represented, respectively, by the late Prof. Ehud Netzer and by Prof. Israel Levine. According to Netzer ${ }^{2}$, Herod was directly involved in the planning of his projects, especially when it came to choosing building materials and the unique landscape in the midst of which the projects were to be constructed. According to Netzer, the king had his own vision of how the palaces he had commissioned were supposed to look - and it was this vision that had prompted the entire building enterprise in the first place. Prof. Levine, on the other hand, has claimed that the monumental projects attributed to Herod were more likely the product of a gifted architectural mind; or

\footnotetext{
${ }^{1}$ For further reading on this matter, see: Foerster, 1996; Lichtenberger, 2009; Peleg-Barkat, 2007; and Roller, 1998.

${ }^{2}$ Netzer, 1980: 45
} 
Gassner E.: Beyond the walls: Locating the common denominator in Herod's Landscape palaces

rather, a team of such gifted architects ${ }^{3}$. Levine claims that there is no sufficient evidence that Herod took an active part in the process of planning and building his projects.

\section{Fig. 1: Herod's Kingdom. Plan by Ehud Netzer; Herodium Excavation Project}

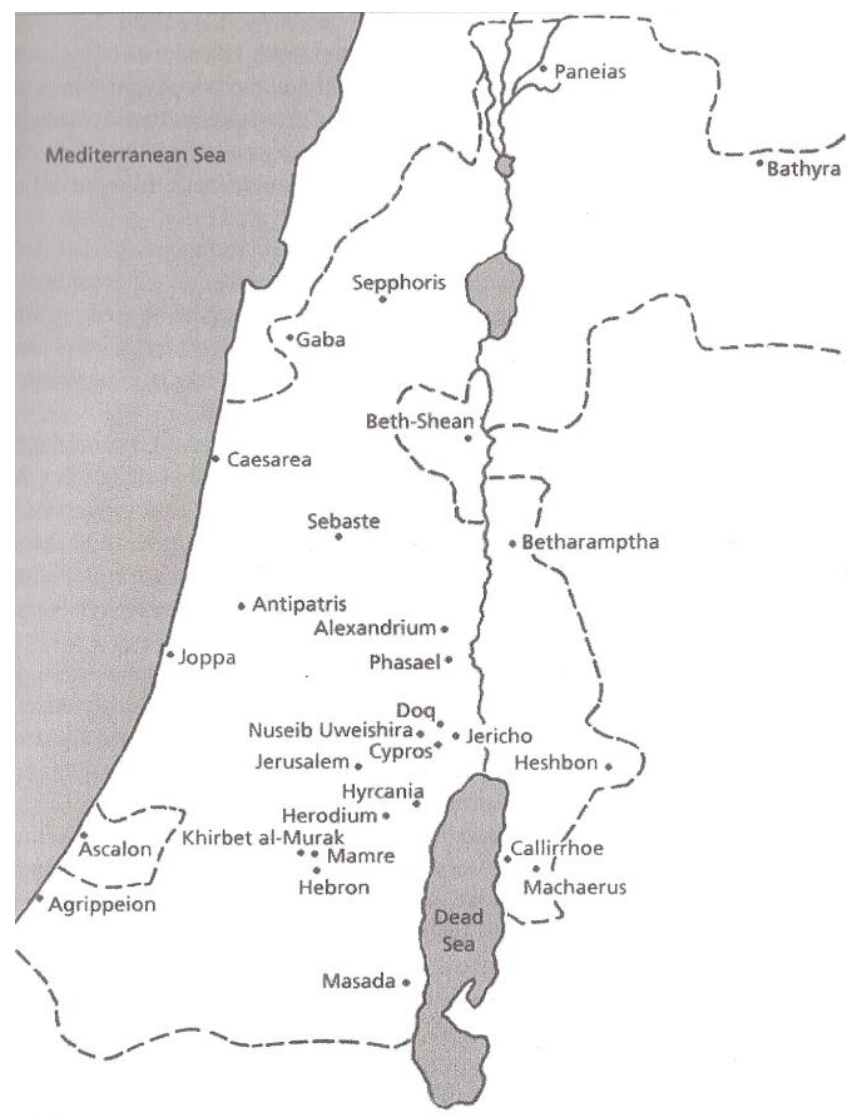

The question of the level of Herod's involvement in his projects was one of the topics I researched for my Master's Thesis paper. To answer this question, among others, I examined the role of the inner structure and the architectural units, as well as their correspondence with one another, in four of Herod's "Landscape Palaces" - so described due to their distinguished relationship with their surroundings. These four palaces - the palace of Lower Herodium, the Northern Palace of Masada, The Promontory Palace in Caesarea Maritima and the Third Winter Palace in Jericho - were chosen as case studies due to their complexity, size, and sophistication. These palaces, built between the years 25-15 BCE, are known for their architectural syncretism - the blend of the local east with the Roman west- that is so characteristic of Herod's projects ${ }^{4}$.

An examination of these palaces' plans, during which I compared the structural units and mapped out all of the architectural elements, brought me to the conclusion that neither of the

${ }^{3}$ Levine, 1980: 52

${ }^{4}$ Gassner, 2015: 2 
palaces was alike. Some of them do share a common location for a specific architectural element (for example, the location of the bedrooms, a large number of reception halls, or some similar attributes appearing in the swimming pools); but this fact alone was not enough to establish the existence of common ground ${ }^{5}$. Thus, I decided to expand the limits of my search and attempt to discover the shared elements outside of the structures' borders.

\section{Fig. 2: Plan of Herodium. Plan by Ehud Netzer; Herodium Excavation Project}

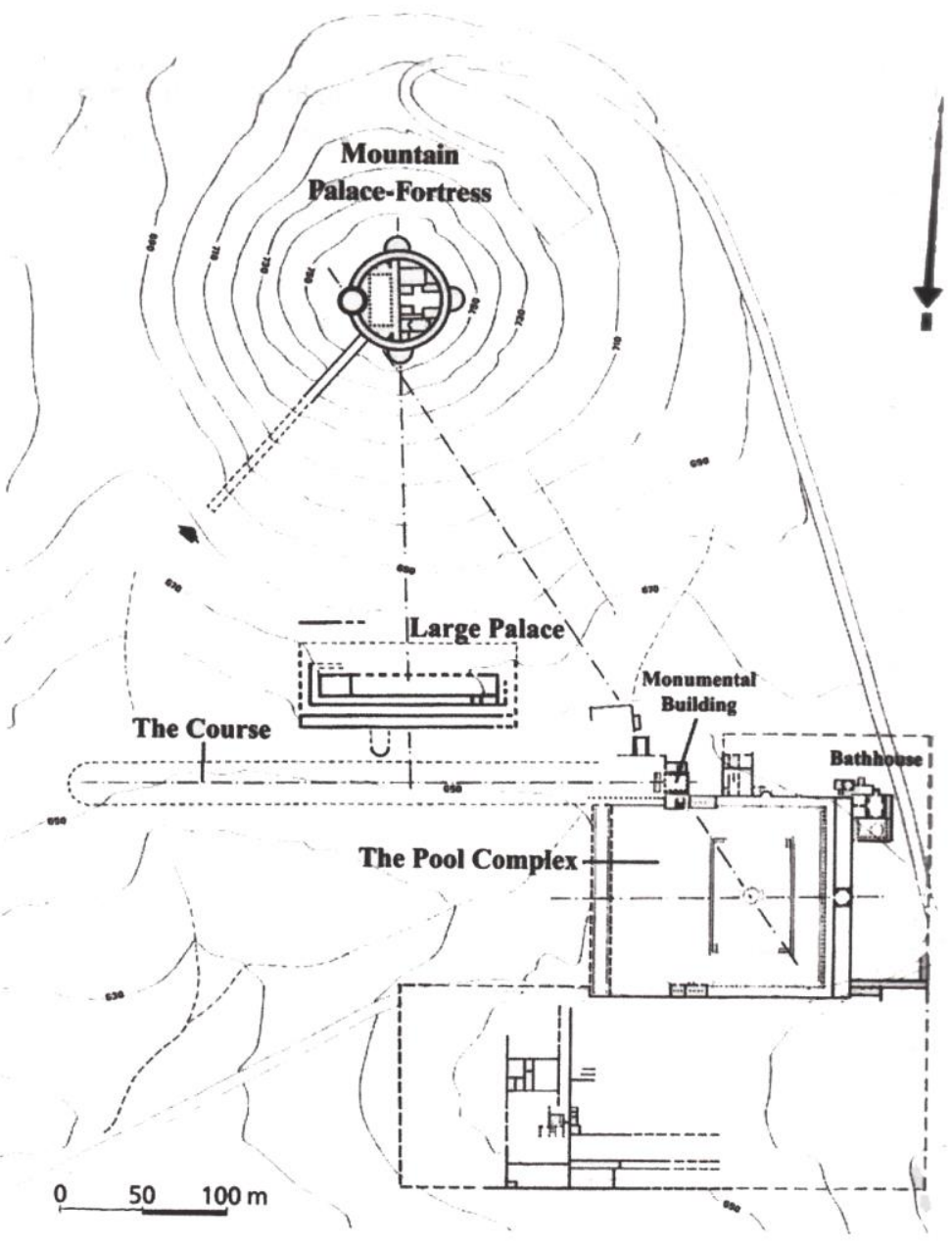

\section{Lower Herodium}

Herodium is located at the edge of the Judean desert, approximately $6 \mathrm{~km}$ southeast of Bethlehem. It is made up of a fortress that stands on top of an artificial hill that was constructed by Herod, and a large Palace complex located at the foot of the volcano-shaped mount. Lower Herodium extends over approximately 15 hectares and consists of the Great

\footnotetext{
${ }^{5}$ Gassner, 2015: 59-61
} 
Gassner E.: Beyond the walls: Locating the common denominator in Herod's Landscape palaces

Place - of which only the foundations and cellars remain; the pool complex; and the 'course,' which had probably served the funerary procession of King Herod in the year 4 BCE. The construction of Lower Herodium itself required the erection of retailing walls, a considerable dumping of fills and cutting into bedrock. The most substantial section of Lower Herodium was built around a large pool, which measured $69 \times 45 \mathrm{~m}$ and was approximately $3 \mathrm{~m}$. deep. The pool was partially hewn into the bedrock and was coated with a gray hydraulic plaster. A round structure in the form of a Tholos stood at the center of the pool. This structure, of which only the foundations have survived, was reachable by boat and likely used as a pavilion or a reception hall ${ }^{6}$. The pool itself was surrounded by a garden, the main part of which was located to the east with smaller stretches on the other sides of it. This complex was surrounded by various structures to its north, west, and south - which probably served as different wings of an administrative complex. The pool itself had several functions; besides being a distinct landscape feature in itself, it had also provided swimming and boating activities and was the only Herodian pool that was not intended solely for recreation but served as a water reservoir as well ${ }^{7}$.

Herodium, in all of its magnificent glory, was Herod's monument to himself: the place where he was buried. It is little wonder, therefore, that he chose to commemorate himself so dramatically.

Fig. 3: Reconstruction of The Northern Palace. Plan by Ehud Netzer; Herodium Excavation Project

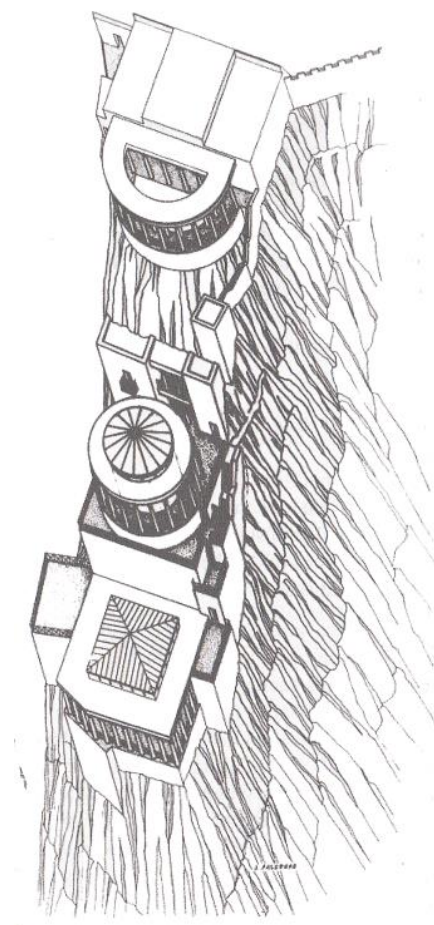

${ }^{6}$ Netzer, 1981: 12-15

${ }^{7}$ Netzer, 2006: 190-191 


\section{The Northern Palace at Masada}

The fortress of Masada is located at the top of a rocky cliff, to the west of the Dead Sea. Herod had two structures built on the hill-top: the Western Palace and the Northern Palace. The latter of the two is undoubtedly one of the most impressive buildings constructed by the king. The palace is built on the northern side of the cliff and makes use of three pre-existing rock terraces by reshaping and adopting them into different forms - the upper terrace into a semicircle, the middle terrace into a circle and the lower terrace into a rectangle. The height difference between the upper and middle levels is approximately $20 \mathrm{~m}$; and approximately $13 \mathrm{~m}$ between the middle and the lower levels ${ }^{8}$ (Fig.4).

Fig. 4: Plan of the Northern Palace. Plan by Ehud Netzer; Herodium Excavation Project

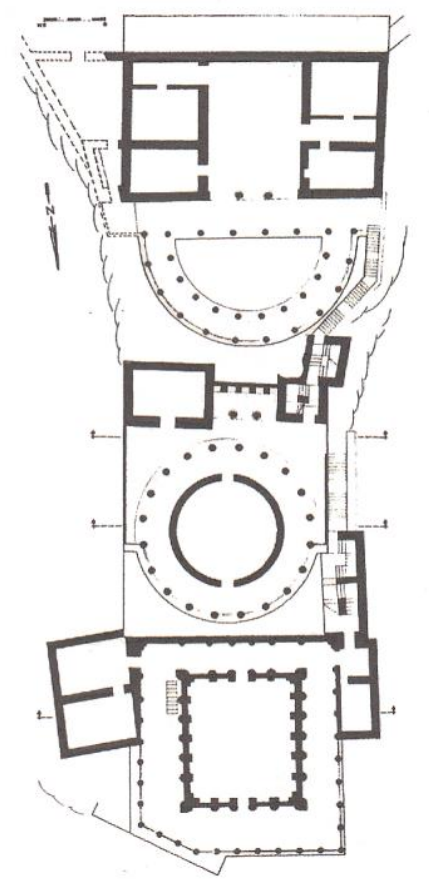

The entrance to the palace was through the upper terrace, which contained two bedroom units, the floors of which were decorated with black and white mosaics, and a semicircular balcony that was surrounded by a double colonnade which revealed the breathtaking view of the Dead Sea. A flight of stairs connecting this terrace to the other two lead from the western end of the balcony ${ }^{9}$. The middle terrace comprised the foundations of a round structure which had consisted of two concentric walls, standing approximately $3 \mathrm{~m}$ apart from each other, and two water installations to the south: one a cistern and the other a ritual bath (miqveh). Though the remains of this terrace are very poorly preserved, there can be no doubt that the circular structure was a Tholos of some sort that served as a reception hall ${ }^{10}$. The lower terrace is the

\footnotetext{
${ }^{8}$ Netzer, 2006: 29

${ }^{9}$ Netzer, 2006: 30

${ }^{10}$ Foerster, 1995:174-179
} 
Gassner E.: Beyond the walls: Locating the common denominator in Herod's Landscape palaces

most magnificent and best-preserved of the three. Topographic limitations caused the north-eastern corner of the hall to be cut off diagonally, creating a nearly square hall $(10.3 \mathrm{x}$ $9.0 \mathrm{~m}$.). The entrance to this level was at the southwest, from the stairway that ran from the upper level. The hall was surrounded by colonnades, with engaged columns on pedestals decorating the walls. Large windows filled out the space between the columns and looked out to the view around the palace. The southern colonnade, with its engaged columns, was cut into the rock. Due to the good state of preservation, we can see that the columns were built in the Corinthian order, with Attic bases; and that the entire hall was lavishly decorated, both with fresco and stucco ${ }^{11}$. Two units were built adjacent to the south-eastern side of the lower terrace: the western unit was small and served as the entrance to the hall, whereas the eastern unit was larger and comprised two levels - the upper one is much eroded, but the remains of two rooms can still be seen. The lower unit sported a small Roman bathhouse ${ }^{12}$.

The location of the Northern Palace is superb. Due to its prime, isolated position, the king's guests enjoyed a staggering view, maximum shade in the hot summer months and a strong sense of security. The halls of the palace turned north, echoing the approaches of Roman architecture $^{13}$. Due to its unmistakable connection to the Landscape around it, namely to the Dead Sea ${ }^{14}$, some have even opted to call the Northern Palace a Villa Maritime ${ }^{15}$.

\section{The Promontory Palace in Caesarea Maritima}

The city of Caesarea Maritima is located on the shore of the Mediterranean Sea. Initially, the city (called Strato's Tower) was of Phoenician origin. It was conquered by the Hasmoneans, reconquered by the Romans and eventually, after years of decline came under the rule of Herod, who turned the decaying town into one of the most famous port cities in the ancient world (Fig. 5).

Fig. 5: Plan of the Promontory Palace. Plan by Ehud Netzer; Herodium Excavation Project

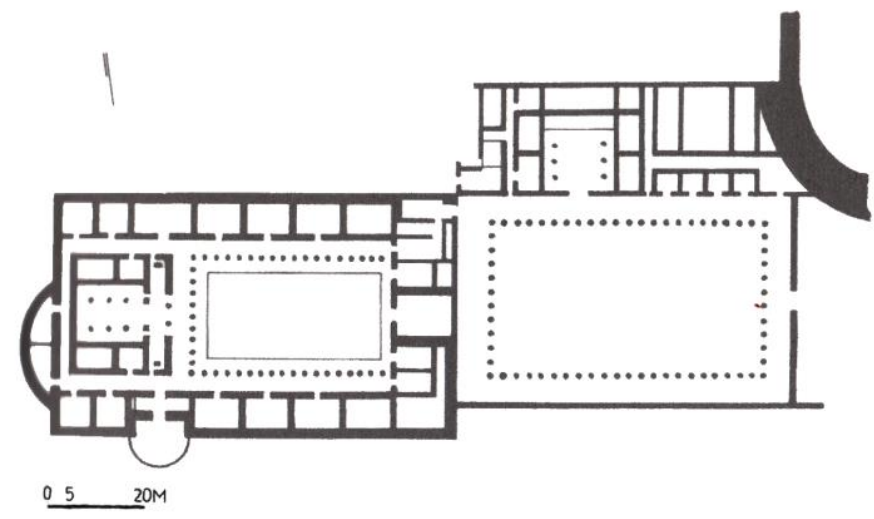

\footnotetext{
${ }^{11}$ Many stucco fragments found on site indicate that the ceiling of the hall was also decorated.

12 Netzer, 2006:32

${ }^{13}$ Vitruvius suggests that reception halls in areas of hot climates face north, in order to enjoy shade and breeze to the best extent (Vitruvius, De Architectura, II, IV, VI).

${ }^{14}$ It is important to understand that during Herod's time the Dead Sea was located much closer to the cliff of Masada than it is now. Unfortunately, 2000 years saw it shrinking and drying up considerably.

${ }^{15}$ Foerster, 1996.
} 
The palace that the king built for himself in Caesarea was constructed atop a promontory rock, located approximately $450 \mathrm{~m}$ south of the harbor. The palace itself was made up of two wings: the lower one was built first ${ }^{16}$ and had a more intimate and private feeling to it, while the upper one was added about ten years later and used mostly for public functions ${ }^{17}$. The lower wing consisted of a series of rooms positioned symmetrically around a rock-cut pool, measuring $35 \times 18 \mathrm{~m}$ in size and $2 \mathrm{~m}$. deep. The pool was surrounded on its western, southern and northern sides by columns, and had small depressions in the colonnade that were probably used for plants ${ }^{18}$. A cluster of rooms built east of the pool consisted of a large hall at the center and two identically-sized rooms at its sides. The large hall probably served as a reception hall, where the king's guests and family took their meals. The pool, which dominated most of the space of the lower wing, was used for bathing and swimming and contained fresh water. This wing had two stories: based on the remains on site; it is safe to presume that the upper level had yet another reception hall and a round balcony, very similar to the one built at the Northern Palace in Masada, which looked to the sea ${ }^{19}$. The upper wing was dominated by a large, rectangular courtyard that was surrounded by columns. A row of rooms that was built to the north of the courtyard included a large hall, measuring $15 \times 17 \mathrm{~m}$. This hall, which likely served as the Throne room or as an audience room for the king, opened directly into the courtyard ${ }^{20}$.

The palace that Herod built for himself in Caesarea was one of the first features seen upon reaching the shores of Judea; together with other important monuments, such as the harbor, and the towering temple for Augustus and Rome. This was a statement of power and control. The Royal Palace, with its foundations in the water, looked as if it was sailing out to greet the incoming ships, and at the same time let them know that its owner was very powerful and had the full support of the budding Empire.

\section{The Third Winter Palace in Jericho}

In the year 15 BCE, Marcus Agrippa arrives at Judea for an official visit and Herod entertains him and his entourage at Caesarea, Samaria-Sebaste, Hyrkania, Alexandrium, and Herodium $^{21}$. Agrippa, much impressed with Herod's impressive projects, decides, upon his return to Rome, to send a team of workers to help the king with future projects. According to Netzer $^{22}$, the Third Winter Palace at the winter resort of Jericho, located in the Jordan Valley, is the product of this gesture of friendship (Fig. 6.).

\footnotetext{
${ }^{16}$ About the year $22 \mathrm{BCE}$, when the construction of the city itself began.

${ }^{17}$ Netzer, 2006: 101

${ }^{18}$ Netzer, 1986.

${ }^{19}$ Netzer, 2006: 108- 109

${ }^{20}$ Netzer, 2006: 111

${ }^{21}$ Josephus, Antiquities

${ }^{22}$ Netzer, 2006: 56-57
} 
Gassner E.: Beyond the walls: Locating the common denominator in Herod's Landscape palaces

Fig. 6: Plan of the Third Winter Palace Complex. Plan by Ehud Netzer; Herodium Excavation Project

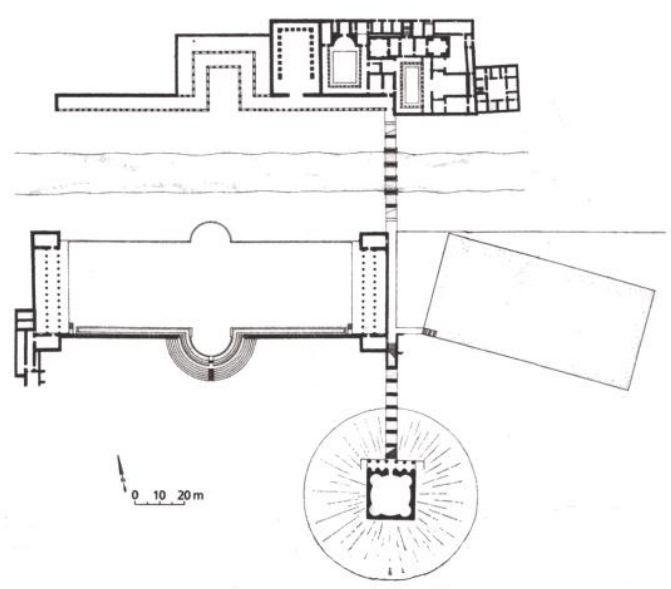

Herod erected three palaces in Jericho during his years of reign, of which the third one is the grandest and most lavish. It is also called the "Opus Reticulatum Palace" due to this distinct Roman building technique that was used in certain rooms in the building. The palace, which takes up approximately 30 hectares, was built on the two banks of the Wadi Qelt. This stream stands dry for most of the year but overflows with water at the end of winter. The palace consisted of four sections: the northern wing, located to the north of Wadi Qelt, where most of the rooms and reception halls were located, and three other wings located to the south of the stream: the "southern tell" at the center, the "sunken garden" to the west, and a huge pool on the east ${ }^{23}$. Even though no such remains were found during excavations, it is presumed that a bridge was built over the stream, to connect the northern wing to its southern brethren (Fig.7.).

Fig. 7: Plan of the Northern Wing. Plan by Ehud Netzer; Herodium Excavation Project

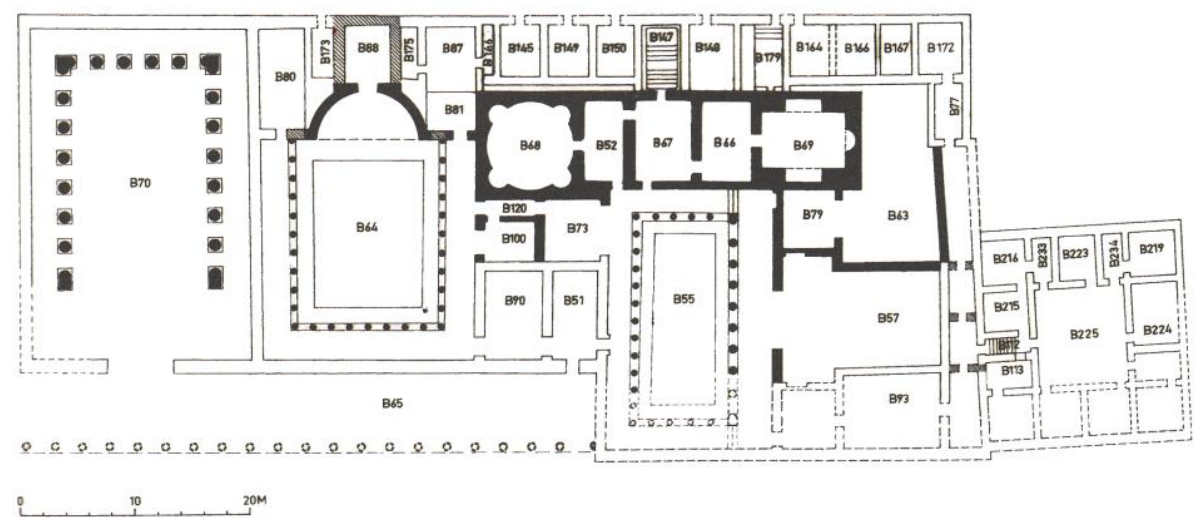

${ }^{23}$ Netzer, 2006: 59 
The northern wing comprised several reception halls, two peristyle courtyards, guest rooms and a Roman bathhouse. Almost all the rooms in this wing were lavishly decorated in fresco $^{24}$ and stucco, with courtyards that turned south towards the view. One of these, Courtyard B64, sported a decorative garden at its center, measuring $9.3 \times 12.7 \mathrm{~m}$., in which seven rows of columns, with a place for about 12 flower pots in each row, were uncovered ${ }^{25}$. The 'southern tell' is a round structure approximately $16 \mathrm{~m}$ in radius, built atop an artificial hill south of the Wadi Qelt stream, of which only the foundations remain. The remains on site included fragments of fresco and terra-cotta decorations, which are extremely rare in Israel ${ }^{26}$. The plan of the round building is very similar to the plan of the laconicum (sweat-room) of the bathhouse located in the northern wing. G.D. Stiebel ${ }^{27}$ offers to identify this structure as a large laconicum with a double floor, thanks to its resemblance to the northern sweat-room and other Roman Laconica of Augustan times, such as the one in Agrippa's Bathhouse in Rome ${ }^{28}$.

The 'sunken garden,' 37 x 112 m, was located southwest of the northern wing, directly in front of the courtyards, so that it was part of the grand view that appeared to the guests of the king. The most dominant part of the garden was its splendid southern façade, which was built into the slope. At the center of this Opus Reticulatum-built façade stood an arrangement of circular benches in the shape of a theater, which served for flowerbeds. An ornamental water channel, $1.5 \mathrm{~m}$ wide, ran lengthwise of this façade. At the eastern and western sides of the garden there stood a pair of stucco and fresco-decorated colonnades. These were built about $2 \mathrm{~m}$ higher than the garden itself, hence the peculiar name. The garden itself was probably fitted with lanes and small, ornamental pools for a nice, enjoyable walk ${ }^{29}$.

The swimming pool, located to the southeast of the northern wing, is the largest of all swimming pools built in Herod's palaces. It is approximately $90 \mathrm{~m}$ long and $42 \mathrm{~m}$ wide and is built off-center. The reason for this irregularity was so that people could sit on the slope and watch the activities in the pool itself ${ }^{30}$. Due to its enormous size, it is safe to presume that, apart from swimming, the pool was used for boating, water sports competitions and perhaps even the reenacting of famous sea battles, such as the Battle of Actium.

\section{CONCLUSION}

If one examines the palaces within context, and not outside of it, and takes into consideration the environment in which these palaces were built, one may notice that the common elements in all palaces are the utilization of the dramatic landscape around them and the unique connection each palace has to water. Herod is known for his blatant disregard of topography and the way he used the impossible landscape around him to construct grandiose building projects. No landscape, however steep or uncooperative it may have been, ever stopped him from building his perfect monuments. Herod ruled the surroundings with the confident hand of a dictator and recruited the scenery to work for him and be part of his

\footnotetext{
${ }^{24}$ Rooms B90 and B51 that served as the entrance to the wing were decorated in the "third Pompeian style".

${ }^{25}$ Netzer, 2006: 62

${ }^{26}$ Netzer, 2006: 69; Viloshni, 2008:546

${ }^{27}$ Stiebel, 2015

${ }^{28}$ This is opposed to Netzer's opinion, who suggests considering this structure as a building with two floors- the lower one serves as a bathhouse and the upper one serves as a reception hall (Netzer, 2006: 69).

29 Netzer, 2006: 65

30 Netzer, 2006: 67
} 
Gassner E.: Beyond the walls: Locating the common denominator in Herod's Landscape palaces

agenda when he built these four palaces. Each of the palaces makes use of an almost unruly landscape to its best advantage and exploits the topography of said landscape to intensify its grandness. Another aspect that all four palaces share, as mentioned above, is the connection to water. The fact that three out of four palaces were built in very arid places serves to reinforce this point further and enhance the contrast between the landscape and the palaces. Even the Promontory Palace in Caesarea, although it was not built in a desert-like environment, was practically constructed in the sea. The addition of a swimming pool for leisure activities further provided one with the sense of a spectacular usage of the landscape. One might think that building vast swimming pools for recreational purposes in arid environments, or so close to the sea, is an unthinkable waste of water; However, it is important to understand that, in Herod's case, this was a statement: it is, first and foremost, a way to exhibit the king's wealth, influence and power. Another very interesting example of the importance of water as a landscape element in Herod's buildings comes in the form of two fragments of fresco decorations recently uncovered in the theater built on the slopes of Herodium (Figs. 8-9).

Fig. 8: Fresco fragment depicting a sacred Nilotic scene. Photo by Gabi Laron; Herodium Excavation Project

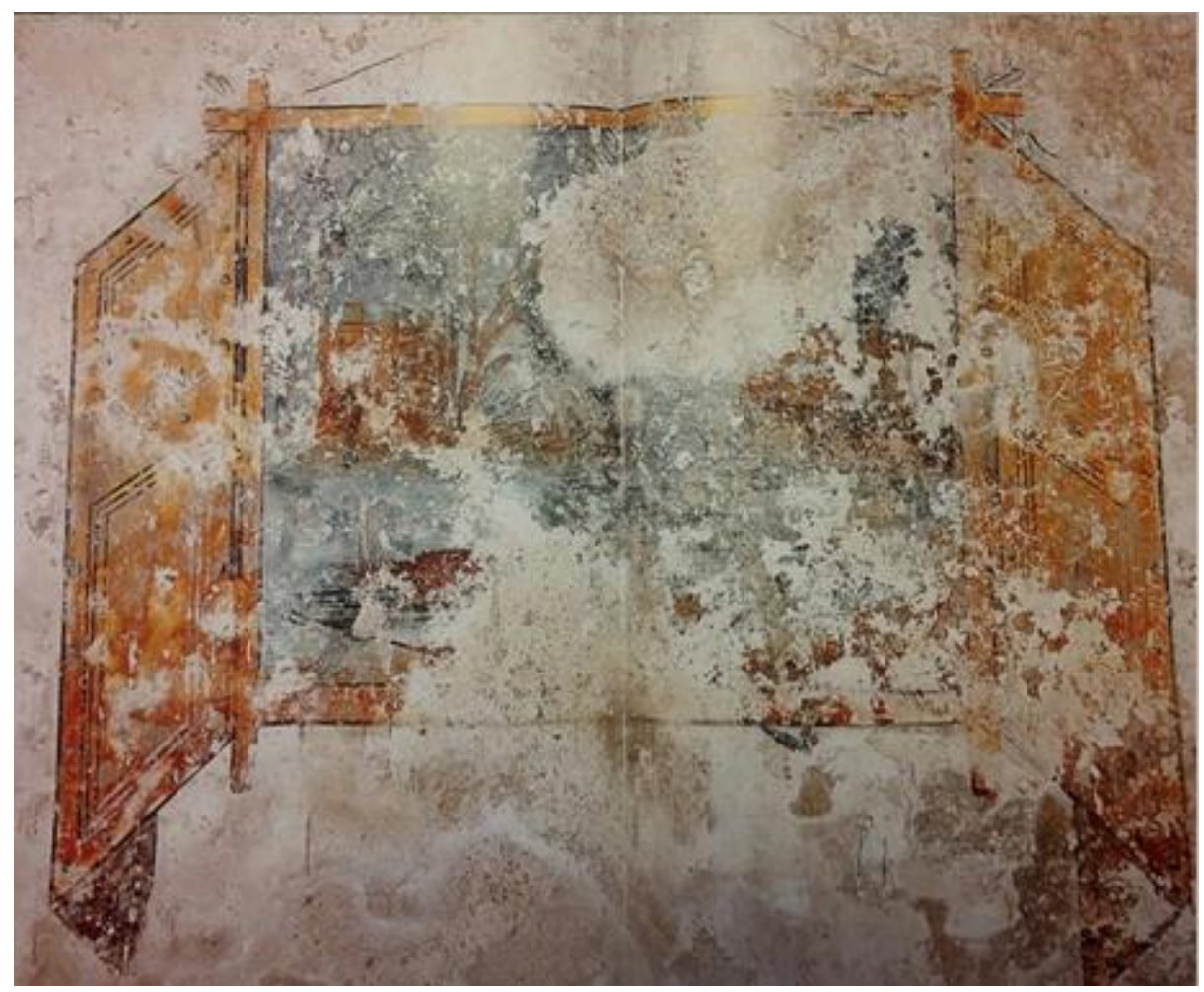




\section{Fig. 9: Fresco fragment depicting a battle ship. Photo by Gabi Laron; Herodium Excavation Project}

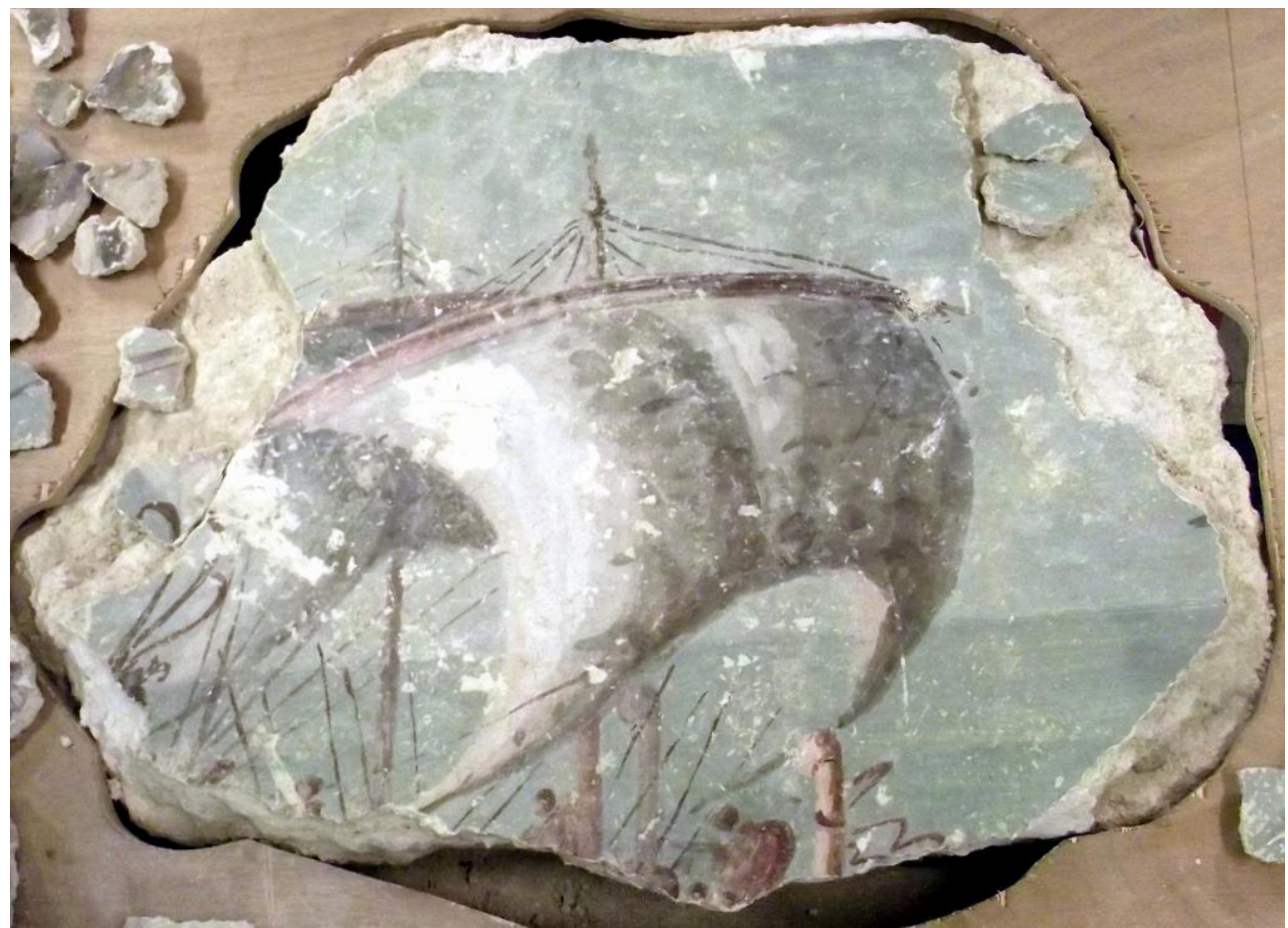

One of the fragments depicts a sacred Nilotic landscape, while the other portrays a segment of a battleship, engaged in a sea battle (probably the famous Battle of Actium mentioned above). It is crucial to understand the significance of the usage of water in these paintings, as it is the only occasion known to us in which Herod violates the Jewish ban on anthropomorphic representation, which he chooses to do with the aid of water. If we go back to the question of Herod's involvement in his own building projects and try to answer it, we can carefully suggest that the lack of a common denominator in the plans of the structures themselves, and the existence of it in their surroundings, indicates that the king was involved in important aspects of the planning of these palaces. If indeed, Levine was right in assuming that the planning of these palaces was the work of one gifted architect, or perhaps even several teams of gifted architects; one would expact to find a certain repetition in the blueprints of the palaces, but not necessarily the same in the surroundings of said buildings. An architect will care more about the plan of the palace itself, than the view around it, and since the element of water and landscape played such a significant role in Herod's power agenda, it seems only logical to assume that the decision where to locate the palaces and what elements to use was left to the King. And so, I propose that both the uniqueness of each plan and the election of the landscape with which the palaces will interact suggest that it was most likely Herod who selected the locations and chose the outline of the magnificent monuments he built as a testament to his power and wealth. 
Gassner E.: Beyond the walls: Locating the common denominator in Herod's Landscape palaces

\section{ACKNOWLEDGEMENTS}

All following plans and illustrations are authorized by Roi Porat, head of the Herodium Excavation project, to be used in this article, courtesy of the Herodium Excavation Project. I would like to thank Roi and the Herodium Excavation Project for granting me the right to use the plans and illustrations here.

\section{REFERENCES}

Flavius Josephus, Jewish Antiquities, Book 16. Hebrew Translation: A. Shalit (1958), Jerusalem.

Foerster, G. (1995). Masada V, The Yigael Yadin Excavations 1963-1965 Final Reports: Art and Architecture, Jerusalem.

Foerster, G. (1996). "Hellenistic and Roman Trends in the Herodian Architecture of Masada", in: Fittschen and Foerster (eds.), Judaea and the Greco-Rpman Worls in the Time of Herod in the Light of Archaeological Evidence: Acts of a Symposiom Organized by the Institute of Archaeology, The Hebrew University of Jerusalem and the Archaeological Institute, Georg-August-University of Gottingen Jerusalem, November $3^{\text {rd }}-4^{\text {th }} 1988$, Gottingen.

Gassner, E. (2015). "Luxurious Functionality": The Role and Nature of the Inner Structure of Herod's Landscape Palaces (Hebrew). M.A. Thesis Dessirtation, Hebrew University of Jerusalem.

Levine, I. (1980). "Toward an Evaluation of Herod the Builder", Cathedra 15, Pp. 52-55 (Hebrew).

Lichtenberger, A. (2009). "Herod and Rome: Was Romanisation a Goal of the Building Policy of Herod?", In: Jacobson \& Kokkinos (eds.) Herod and Augustus, Papers Presented at the IJS conference $21^{\text {st }}-23^{\text {st }}$ June 2005 (pp. 43-62), Leiden-Boston.

Netzer, E. (1980). "Herod's Building Projects- State Necessity or Personal Necessity?" Cathedra 15. Pp. 38-51 (Hebrew).

Netzer, E. (1981. Greater Herodium (Qedem 13), Jerusalem.

Netzer, E (1986). "The Main Excavation Area: Description and Stratigraphy", In: Levine and Netzer (eds.) Excavations at Caesarea Maritima:1975, 1976, 1979-Final Report, (Quedem 21) (pp. 16-65), Jerusalem.

Netzer, E. (2006). The Architecture of Herod the Great Builder, Tubingen.

Peleg-Barkat, O (2007). The Herodian Architectural Decoration in Light of the Finds from the Temple Mount Excavations, Thesis Submitted for the Degree "Doctor of Philosophy", Hebrew University of Jerusalem.

Roller, D.W. ( 1998). The Building Program of Herod the Great, University of California Press.

Stiebel, G.D. (2015). "Aqua Regis"- Fountains of King Herod the Great", In: Weiss (ed.) Eretz Israel 31, Ehud Netzer Volume (pp. 426-444), The Israel Exploration Society, Jerusalem.

Viloshni, N. (2008). "Terra-cotta Architectural Fragments", In: Rozenberg (ed.) Hasmonean and Herodian Palaces at Jericho: Final Reports of the 1973-1987 Excavations, Vol. IV: The Decoration of Herod's Third Palace at Jericho (pp. 545-547), Jerusalem.

Vitruvius, De Architectura. Hebrew Translation: R. Reich (1997), Tell Aviv. 